\title{
국제개발협력과 시민사회(CSO)의 역할: 부산총회 이후의 맥락에서
}

이 성 훈 (KoFID 운영위원)

\section{1. 들어가면서}

\section{목 차}

2. 부산 세계개발원조총회와 시민사회의 역할

3. 부산 세계개발원조총회 이후 국제 시민사회단체의 대응과 전략

4. 부산 세계개발원조총회와 한국 시민사회

5. 한국 시민사회단체 개발효과성 증진을 위한 제안

\section{1. 들어가면서}

부산 세계개발원조총회는 작년 12 월 1일 '효과적인 개발협력을 위한 부산 파트너십' 과 정치 선언문을 채택하고 성공적으로 마무리되었다. 약 3 개월이 지난 현재 국내외적으로 각국 정부와 시민사회는 부산총회 자체에 대한 자체 평가를 마무리하고1) 부산 파트너십의 핵심 내용인 효과 적인 개발협력을 위한 글로벌 파트너십(Global Partnership for Effective Development Cooperation)의 구성과 운영방안 및 글로벌 모니터링 체제와 평가지표를 올해 6월말까지 만드 는데 참여하고 있다. 이와 관련하여 지난 2월 13-14일 파리에서는 포스트 부산 임시그룹 (Post Busan Interim Group) 첫 회의가 열렸다.

1) 시민사회의 관점에서 본 부산총회 결과문서에 대한 평가는 이성훈, "시민사회가 바라보는 부산총회의 성과와 향후 과제" 국제개발협력 (2011, No 4) 참조 
국제 시민사회의 경우 부산총회에서 국제시민사회를 대표한 두 네트워크인 BetterAid와 시 민사회 개발효과성을 위한 오픈 포럼(Open Forum)은 지난 2월 21-23일 필리핀 세부에서 부 산총회 결과에 대한 평가 및 향후 국제시민사회의 전략에 대한 논의를 하였다. 국내에서는 국제 개발협력시민사회포럼(KoFID)이 작년 12월 15일 부산 세계시민사회포럼(BCSF)과 부산 총회 결과에 대한 자체 보고회를 가졌고 올해 2월 2-3일 부산총회 평가를 주제로 아시아에서 10여 명의 시민사회 대표 포함 50 여명의 정부 및 시민사회단체 대표가 참여한 가운데 제 2 회 서울시 민사회포럼을 개최하였다. 이보다 앞서 KoFID 대표는 1월 중순 일본 정부와 시민사회가 공동 으로 주최한 부산총회 결과에 대한 평가회의에 참여하기도 하였다.

한편 국제시민사회는 올해 6월, 1992 년 리우 환경회의 20주년을 기념하여 브라질 리우에서 개최되는 지속가능발전유엔회의(UNCSD) - '리우+20' - 와 2015년 이후 새천년개발목표 (MDGs)를 대체할 개발의제와 목표에 대한 유엔의 논의에도 참여하고 있다.

이 글은 국제개발협력에서 시민사회의 역할을 부산총회 이후 전개되는 국제적 담론과 의제 그 리고 이에 대한 국제시민사회의 대응의 맥락에서 비판적으로 살펴보고자 한다. 이를 위해 먼저 부산총회 결과문서에서 정식화된 시민사회의 역할과 그 의미를 비판적으로 살펴보고 필리핀 세 부에서 개최된 국제시민사회의 논의 결과 특히 국제시민사회의 활동 내용과 방향을 소개하고자 한다. 그리고 부산총회 전후한 한국 시민사회의 변화와 도전을 한국 시민사회 개발효과성 증진 의 관점에서 제시하고자 한다.

\section{2. 부산 세계개발원조총회와 시민사회의 역할}

부산총회는 정부와 국제기구 대표 이외에도 기업, 지방정부, 의회, 시민사회 등 다양한 행위 자가참여한 다자간 협의의 장이었다. 다양한 비국가행위자 (Non-state actors) 가운데 시민 사회는 회의 전 기간 전후하여 가장 많은 주목을 받았고 총회의 결과 내용에 적지 않은 영향을 주었다는 평가를 받았다.

시민사회의 관점에서 볼 때 부산총회는 내용과 형식 면에서 이전의 회의에 비해 매우 의미있 는 진전을 이룬 역사적인 회의라고 볼 수 있다. 공식 참가자 300 명 이외에도 많은 시민사회단체 대표자가 다양한 형식으로 부산총회에 직접 참석하여 시민사회는 정부 대표를 제외하고 수적으 로 가장 큰 집단이었다. 이러한 양적인 것보다 더 중요한 것은 부산총회의 내용에 대한 시민사 회의 실질적인 기여라고 볼 수 있다. 
시민사회 대표는 업저버가 아닌 정식 참가자의 일원으로 참가하였고 시민사회의 대표자가 $\mathrm{OECD}$ 의 원조효과성 실무그룹 집행위원회(Executive Committee)와 협상대표(Sherpa)의 일 원으로 부산 총회 의제 논의 초기부터 후반부 최종문서 협상 및 채택에 이르는 전 과정에 중요 한 행위자로 참가하였다. 더 나아가 시민사회대표는 의회와 기업의 독자적인 대표가 없는 가운 데 비국가행위자 가운데는 유일하게 협상대표에 포함되었다는 점을 주목할 필요가 있다. 이는 다른 집단에 비해 다양하고 이질적인 구성에도 불구하고 스스로 효율적인 대표조직을 만들어 시종일관 효과적으로 준비 과정에 개입해 왔기 때문에 가능한 것이었다. 이는 정부간 회의에서 이례적인 사례로 개발원조 분야에서 시민사회의 영향력이 실질적으로 증대되었음을 반증하는 것이었다. ${ }^{2)}$

아래의 표에서 보듯이 2005년 부산과 2008년 아크라 회의의 최종 결과 문서는 개도국(수원 국) 선진국(공여국)의 정부 대표 및 양자와 다자간 개발원조기구만을 회의의 주체로 인정하였 다. 이에 비해 2011년 부산총회는 기존의 정부와 정부간 기구 대표 이외에 시민사회단체를 기 업, 의회, 지방 정부 및 지역기구와 함께 정식 참가자로 결과문서 서두에 명시하였다. 이러한 변 화는 부산총회가 국제개발협력이 더 이상 정부만이 아니라 다양한 행위자의 공동 과제라는 역 사적 인식의 전환을 의미하는 것이었다.

\section{표 1 : 파리-아크라-부산회의 비교 : 참가주체와 시민사회의 참가 자격}

\begin{tabular}{c|l}
\hline 2005년 파리 & $\begin{array}{l}\text { 회의의 참가자와 시민사회 참가 자격 } \\
\text { Ministers of developed and developing countries responsible } \\
\text { for promoting development and Heads of multilateral and } \\
\text { bilateral development institutions, }\end{array}$ \\
\hline 2008년 아크라 & $\begin{array}{l}\text { Ministers of developing and donor countries responsible for } \\
\text { promoting development and Heads of multilateral and bilateral } \\
\text { development institutions }\end{array}$ \\
\hline & $\begin{array}{l}\text { Heads of State, Ministers and representatives of developing } \\
\text { and developed countries, heads of multilateral and bilateral } \\
\text { institutions, representatives of different types of public, civil } \\
\text { society, private, parliamentary, local and regional organizations }\end{array}$ \\
\hline
\end{tabular}

2) 2008년 OECD/DAC 회원국들의 NGO에 대한 ODA지원규모는 순지출 기준 양자간 ODA의 $11.14 \%$ 이르고 있다. 또한 NGO자체 개발협력 자금규모도 지속적으로 증가하였다. 1991년과 1992년 평균 9.8\%에 불과했던 ODA자금 에 대비하여 2009년에는 NGO 자체적으로 모금된 자금집행의 비율이 $18.4 \%$ 까지 증가하였다. 
한편 부산총회는 시민사회의 국제개발협력에서의 역할 관점에서 볼 때도 이전 회의에 비해 큰 진전을 이루었다.

먼저 2005년 파리선언은 수원국이 개발정책과 전략 및 사업이행을 조정하는 과정에 시민사 회와 기업의 참여를 권고한 제 14 항에서 시민사회를 간단히 언급하는데 그쳤다. ${ }^{3)}$ 파리의 제 2 차 원조효과성 회의에 십 여개의 국제 개발단체 대표가 참석했지만 업저버 신분이었고 내용적으로 도 별다른 기여를 하지 못하였다.

이에 비해 2008년 아크라는 제 13 항목에서 일국적 차원의 개발 정책 논의에 시민사회단체의 참여를 강조하였고 시민사회단체의 역량 강화 또한 강조하였다. ${ }^{4}$ 더 나아가 제 20 항목에서 정 부와 국제기구 대표는 시민사회단체와의 협력 강화를 강조하면서 "독립적인 개발 주체로서의 $\mathrm{CSOS}$ 가 스스로의 권리를 가지고 정부와 기업을 보완시키는 노력에 더 깊이 관여하고 $\mathrm{CSO}$ 가 스스로의 잠재성을 최대한 발휘할 수 있도록 기여하는데 관심을 가지고 있다”고 밝혔다. 그리 고 보다 구체적으로 "CSOs가 파리선언의 원조 효과성의 원칙을 $\mathrm{CSO}$ 의 관점에서 어떻게 적용 할지 성찰할 것을 권고하며, $\mathrm{CSO}$ 가 $\mathrm{CSO}$ 개발 효과성을 증진시키기 위해 $\mathrm{CSO}$ 주도의 다양한 이해관계자의 협력 과정에 참여하는 제안을 환영하며, 이러한 과정의 일환으로 i) CSO 와 정부 프로그램의 협력과 조정을 향상시키고 ii) 결과에 대한 $\mathrm{CSO}$ 의 책무성을 제고하며 iii) $\mathrm{CSO}$ 활 동에 관한 정보를 개선하고자 한다" 고 표명하였다. ${ }^{5)}$

3) Para 14. Partner countries commit to:

- Take the lead in co-ordinating aid at all levels in conjunction with other development resources in dialogue with donors and encouraging the participation of civil society and the private sector.

4) We will broaden country-level policy dialogue on development

Para 13. We will engage in open and inclusive dialogue on development policies. We acknowledge the critical role and responsibility of parliaments in ensuring country ownership of development processes. To further this objective we will take the following actions:

a) Developing country governments will work more closely with parliaments and local authorities in preparing, implementing and monitoring national development policies and plans. They will also engage with civil society organisations (CSOs).

b) Donors will support efforts to increase the capacity of all development actors ? parliaments, central and local governments, CSOs, research institutes, media and the private sector ? to take an active role in dialogue on development policy and on the role of aid in contributing to countries' development objectives. 
아크라에서 열린 사전 시민사회포럼에 약 500 명 이상이 참여했지만 실제 본회의에 참여한 시 민사회대표는 30 명에 그쳤다. 그러나 시민사회는 처음으로 자체 조직화 작업을 통해 공동의 입 장의 가지고 회의에 참여하였고 선언문에서 보듯이 시민사회가 스스로의 권리를 지닌 독립적인 행위자로 인정받는 성과를 거두었다.

아크라의 성과를 바탕으로 부산총회에서 시민사회는 질적으로 적지 않은 성과를 이루었다. 부산총회 결과문서는 제 22 항에서 시민사회의 역할과 의제에 대해 다루고 있는데 역할은 아래의 다섯 가지로 세분화하여 명시하였다.

첫째, 주민의 권리 주창 능력배양 (enable people to claim their rights)

둘째, 권리에 기반한 접근을 증진 (promoting rights-based approaches)

셋째, 개발정책과 파트너십을 형성하고 (shaping development policies and partnerships)

넷째, 개발정책의 이행을 모니터 및 감시하고 (overseeing their implementation)

다섯째, 국가가 제공하는 서비스를 보완하는 영역에 서비스를 제공 (provide services in areas that are complementary to those provided by states)

그리고 부산총회는 이러한 시민사회의 역할에 대한 인식을 바탕으로 부산총회의 모든 참가자 는 “시민사회단체가, 국제적으로 합의된 권리에 부합하면서 개발에 대한 시민사회단체의 기여 를 극대화할 수 있는 환경을 구축하는데 초점을 맞추어, 독립적인 개발 주체로서 역할을 다 할 수 있도록 각자의 약속을 충실히 이행하고, 시민사회단체가 이스탄불 원칙과6) 시민사회단체 개

5) We will deepen our engagement with civil society organisations

Para 20. We will deepen our engagement with CSOs as independent development actors in their own right whose efforts complement those of governments and the private sector. We share an interest in ensuring that CSO contributions to development reach their full potential. To this end:

a) We invite CSOs to reflect on how they can apply the Paris principles of aid effectiveness from a cSO perspective.

b) We welcome the CSOs' proposal to engage with them in a CSO-led multistakeholder process to promote CSO development effectiveness. As part of that process, we will seek to i) improve coordination of CSO efforts with government programmes, ii) enhance CSO accountability for results, and iii) improve information on CSO activities.

c) We will work with CSOs to provide an enabling environment that maximises their contributions to development. 
발효과성에 대한 국제 프레임워크(International Framework for CSO Development Effectiveness)를7) 바탕으로, 개발효과성에 대한 시민사회단체의 기여와 책무성을 강화하는 실천을 이행할 수 있도록 권장한다" 고 하였다. ${ }^{8)}$

부산총회에서 언급한 시민사회의 역할 다섯 가지는 2008년 아크라에 시민사회를 '독립적인 개발 행위자' 의 내용을 보다 구체화한 것이다. 이 가운데 처음 두 가지는 인권에 기반한 접근으 로 개발협력의 기본적인 원칙이자 접근을 말하고 셋째와 넷째는 에드보커시(advocacy) 그리고 마지막은 개발현장에서의 서비스제공 사업 (service delivery)를 의미한다. 즉 부산총회는 개 발협력 $\mathrm{CSO}$ 의 역할을 기본적으로 현장 사업과 애드보커시 둘로 구분하고 둘 모두 인권에 기반 한 접근을 해야 한다는 것을 강조하고 있다.

한편 시민사회의 개발효과성 관련하여 부산총회는 2008년 아크라 이후 시민사회단체가 스스 로 만든 이스탄불 원칙과 이의 이행을 위한 시앰립 국제프레임워크를 인정하였다. 이스탄불 원 칙 인정은 Open Forum이 아크라 이후 2009년부터 2년 여 에 걸친 시민사회의 광범위한 논의 과정과 결과에 정당성을 부여한 것으로 부산총회 최대의 성과로 꼽히는 것이었다. ${ }^{9)}$ 그러나 이 와 관련한 정부의 역할과 책임을 다룬 정책환경 조성 (enabling environment)에 대해서는 2008년 아크라 수준을 넘어서는 약속이 없어 한계로 지적되었다.

6) 이스탄불 원칙의 공식명칭은 "시민사회단체 개발효과성을 위한 이스탄불 원칙"으로 2010년 6월 이스탄불에서 열린 Open Forum의 제1차 세계총회(Global Assembly)에서 채택되었다. 구체적 내용은 아래의 8개 항목으로 구성되어 있다.

(1) 인권과 사회적 정의의 존중과 증진

(Respect and promote human rights and social justice)

(2) 여성과 여아의 권리를 증진하면서, 젠더 평등과 형평성 구현

(Embody gender equality and equity while promoting women and girls' rights)

(3) 주민(people)의 주체적 역량제고, 민주적 오너십과 참여

(Focus on people's empowerment, democratic ownership and participation)

(4) 환경의 지속가능성 증진(Promote environmental sustainability)

(5) 투명성과 책무성 실행(Practice Transparency and accountability)

(6) 공정한 파트너십과 연대 추구(Pursue equitable partnerships and solidarity)

(7) 지식을 창출하고 공유하며, 상호학습 추진

(Create and share knowledge and commit to mutual learning)

(8) 긍정적이고 지속가능한 변화를 실현하기 위해 약속

(Commit to realizing positive sustainable change)

7) 국제프레임워크는 이스탄불원칙을 실현하는 가이드라인 성격을 지닌 문서로 2011년 6월 캄보디아 시엠립에서 개 최된 Open Forum 제2차 총회에서 채택되었다. Open Forum은 이후 프레임워크를 구체적인 실천할 수 있는 행동지침과 도구(Toolkit)를 현장사업과 애드보커시 둘로 나누어 발간하였다. 
표 2 : 파리-아크라-부산회의 비교 : 시민사회의 역할 관점에서

\begin{tabular}{c|l}
\hline & \multicolumn{1}{c}{ 시민사회의 역할 } \\
\hline 2005년 파리 & $\begin{array}{l}\text { 14항 주인의식에서 수원국이 개발정책과 전략 및 사업이행을 조정하는 } \\
\text { 과에 시민사회와 기업의 참여를 권고 }\end{array}$ \\
\hline 2008년 아크라 & $\begin{array}{l}\text { 13항 일국적 개발정책 대화에서 지방정부와 국회와 함께 시민사회의 참여 언급 } \\
\text { 20항 CSO의 개발효과성과 이를 가능케하는 환경 (enabling environment) }\end{array}$ \\
\hline 2011년 부산 & 22항 CSO의 구체적 역할과 이스탄불 원칙 및 국제프레임워크 인정 \\
\hline
\end{tabular}

\section{3. 부산 세계개발원조총회 이후 국제 시민사회단체의 대응과 전략}

\section{1) 세부 회의의 논의 결과}

앞에서 간단히 언급했듯이 BetterAid와 Open Forum의 두 네트워크를 중심으로 부산총회 에서 참여한 시민사회단체 대표는 지난 2 월 필리핀 세부에서 3 일간의 논의를 거쳐 향후 활동 목 표와 방향 그리고 가버넌스의 틀에 대한 합의를 도출하였다. ${ }^{10)}$

회의의 결과를 요약한 세부합의(Cebu Consensus)에 따르면 2008년 아크라 이후 2011년 부 산총회까지 정책 애드보커시 중심의 BetterAid와 시민사회 개발효과성을 위한 원칙과 가이드

8) 22. Civil society organisations (CSOs) play a vital role in enabling people to claim their rights, in promoting rights--?based approaches, in shaping development policies and partnerships, and in overseeing their implementation. They also provide services in areas that are complementary to those provided by states. Recognising this, we will:

a) Implement fully our respective commitments to enable CSOs to exercise their roles as independent development actors, with a particular focus on an enabling environment, consistent with agreed international rights, that maximises the contributions of CSOs to development.

b) Encourage CSOs to implement practices that strengthen their accountability and their contribution to development effectiveness, guided by the Istanbul Principles and the International Framework for CSO Development Effectiveness.

9) 자세한 과정에 대해서는 손혁상 (2011) 참조 
라인 개발에 중점적으로 Open Forum 둘로 양분되어 활동해온 국제시민사회는 올해 6월까지 각자의 사업을 마무리하고 9 월경 단일한 네트워크로 통합할 예정이다. 9월까지의 13 명의 대표 로 구성된 G13은11) 세부에서의 논의를 바탕으로 단일한 가버넌스 운영 방안을 만드는 과제를 부여받았다. ${ }^{12)}$

새로운 네트워크는 부산총회 이전에 두 네트워크가 공동으로 작성한 정책 애드보커시 기조에 기반하여 1) 부산, 아크라 및 부산의 공약의 충실한 이행, 2)인권에 기반한 접근의 실행을 통한 개발효과성 강화, 3) 스스로의 권리를 지닌 독립적인 개발 행위자로의 시민사회단체 역할 강화 와 이를 가능케 하는 정책 및 제도적 환경 (enabling environment) 조성, 그리고 4) 균등하고 정의로운 개발협력체제의 구축을 주요 활동 영역으로 재천명하였다.

그리고 이를 위한 실천 전략으로 상향식 참여를 바탕으로 일국적, 지역적, 글로벌 차원의 연 계 강화하되 Global Light, Country Heavy의 원칙에13) 따라 일국적 차원에서의 이행과 소지 역(sub-regional) 차원에서의 협력과 조정 강화, 인권에 기반한 접근 등이 강조되었다.

새로운 네트워크은 글로벌 조정 및 협의 기구와 사무국, 그리고 주제별 실무분과와 국가별/지 역별 그리고 섹터별 담당자로 구성될 예정이다. 보다 구체적으로 새로운 네트워크의 가버넌스

10) 국제 시민사회는 BetterAid와 Open Forum이란 두 개의 국제적 플랫폼을 중심으로 부산총회를 준비하고 참여 하였다. 둘다 2008년 아크라 회의를 계기로 출범하였는데 Open Forum은 시민사회단체의 개발효과성과 이를 가능케하는 정책 및 제도적 환경(enabling environment)를 주제를 중심으로 활동을 전개해온 반면, BetterAid 는 원조효과성과 개발효과성을 의제로 정책 애드보커시 활동에 주력하였다. 내부적으로는 두 개의 네트워크이지 만 $\mathrm{OECD}$ 와의 관계 등 국제기구에서의 대표성에서는 BetterAid 플랫폼 이름으로 이루어져왔다. 두 네트워크의 구성 및 성격 그리고 부산총회의 준비 과정에서의 활동에 대해서는 손혁상 글 참조.

11) G13은 부산총회 직후인 작년 12월 2일 시민사회 평가회의에서 부산총회 후속 이행과정을 이끌어갈 대표기구로 만들어졌다. G13은 BetterAid와 Open Forum의 대표 2명, 그리고 아태지역, 아프리카, 중동과 북아프리카 (MENA), 중남미, 북미, 유럽 지역 대표 6명, 노동, 여성, 농업/농민 섹터 대표, 글로벌 NGO와 종교기반 시민사회 단체 대표 5 명 모두 13 명으로 구성되었다.

12) 새 네트워크의 명칭 관련해서는 세부에서 《CSO Partnership / Forum for Development Effectiveness 》,

《Global CSO Partnership for Effective Development 》, « CSO Forum for Better Development - CFBD

», 《 CSO Platform for Development Effectiveness 》, 《Alliance (of CSOs) for Human Rights in Development 》 등 다양한 제안이 있었고 향후 보다 광범위한 의견수렴을 거쳐 확정할 예정이다.

13) Global Light, Country Heavy는 부산총회 이행의 기본 원칙으로 부산총회 이후 글로벌 차원의 새로운 조직이 나 기구 없이 최소한의 모니터와 정책 조정 업무만을 수행하고 대신 일국적 차원에서의 이행에 보다 많은 노력을 강조하고 있다. Country Heavy라는 표현이 개별국가 특히 수원국에 더 많은 책임을 부과한다는 의미로 해석될 수 있다는 지적이 있어 이후 country focused로 변경되었다. 
체제는 전체합의를 기반으로 의사결정을 하며, 2 년 임기 2 명 이상의 공동의장을 두며, 의장 역 할과 사무국 역할을 분리하고 원주민, 장애인, 청년 등 소외된 그룹의 참여와 대표성을 강화하 고 독립적인 책무성 강화 위원회를 구성하고 부산총회에서 만들어진 빌딩블록(Building Blocks)과 연동된 정책개발과 대화를 촉진하는 역할을 할 예정이다.

\section{2) 새로운 통합 네트워크의 성격과 의의}

세부합의에 따라 올해 9월 출범 예정인 새로운 네트워크는 성공적으로 출범한다면 국제개발 협력 분야 국제시민사회 네트워크에서 제 1 세대의 Social Watch와 제2세대의 지구촌빈곤퇴치 글로벌네트워크 (GCAP)에 이어 제3세대의 흐름을 주도하는 역할을 할 것으로 기대된다.

국제개발 분야에서 애드보커시 중심의 광범위한 국제 시민사회 네트워크가 만들어진 것은 90 년대 초 탈냉전 시기였다. 그 이전에 국제 시민사회는 개별 단체나 플랫폼 중심으로 활동해오 다가14 탈냉전과 함께 유엔 주도의 대규모 국제회의를 계기로 국제적 차원에서 네트워크를 결성 하기 시작하였다. 보다 구체적으로 1992년 리우 환경회의를 필두로 1993년 비엔나 인권회의, 1995년 코펜하겐 개발개발정상회의, 1995 년 북경 여성회의 등 국제개발 관련 주요 의제에 대한 유엔 주도의 대규모 회의에 시민사회가 대거 참여하면서 자연스럽게 지역적, 지구적 네트워크 가 활성화되었다.

90년대 국제개발 분야의 1세대는 1995년 코펜하겐 사회발전정상회의(World Summit for Social Development)를 계기로 형성된 Social Watch를 들 수 있다. Social Watch는 연례보 고서 발간을 통해 시민사회의 시각에서 대안적인 국제개발 담론과 정책 대안을 만들고 확산하 는 역할을 수행해왔다. ${ }^{15)}$

제2세대에 해당하는 지구촌빈곤퇴지시민연대(GCAP)는 2000년 밀레니엄 정상회의의 개발의

14) 개별 단체로는 1910년대 창립된 세이브 더 칠드런, 1940년대 옥스팜, 1950년 한국에서 출범한 월드비전 그리고 1970년대 ActionAid 등이 대표적이다. 이 단체에 대한 간략한 소개는 한재광 (2010) 참조.

15) 시기적으로 제1세대에 해당하는 Reality of Aid는 개발원조에 대한 모니터 보고서를 작성하는 네트워크로 90년 대 초반에 결성되었고 BetterAid의 발족에 중요한 기여를 하였다. 90년대 년대 후반 영국의 기독교 기반 단체를 중심으로 전개한 외채탕감 주빌리 캠페인 또한 제 1 세대의 대표적인 운동이었다. 그러나 주빌리 캠페인은 2000 년 대희년 이후에 지구적 차원의 조직화로 이어지지는 못했다. 대신 주빌리 캠페인에 참가한 개도국 시민사회단체를 중심으로 남반구 주빌리 (Jubilee South)란 이름으로 현재까지 외채탕감 캠페인을 전개하고 있다. 
제를 토대로 2002년 유엔이 정식화한 새천년개발목표(MDGs)에 대한 시민사회의 비판적 개입 을 목적으로 2004년 1월 세계사회포럼의 참가 단체를 중심으로 출범하였다. 초창기 글로벌 차 원의 시민참여를 위해 1990년대 초 창립된 CIVICUS가 사무국 역할을 하다가 이후 독자적인 사무국을 만들어 독립하였다. GCAP은 유엔의 밀레니엄 캠페인과 파트너십 관계를 유지하면 서 시민사회 기반의 MDG 이행 캠페인을 주도해왔고 해마다 10 월 MDGs 이행 촉구 행사를 Whiteband란 이름으로 전지구적으로 전개해왔다. 최근에는 2008년 말 G20 정상회의를 계 기로 G8 및 G20 정상회의 실무그룹을 결성하는데 주도적 역할을 하였다.

2008년 아크라 회의를 계기로 출범한 BetterAid와 Open Forum은 제3세대에 해당한다고 볼 수 있다. BetterAid 네트워크는 구성원의 측면에서 볼 때 노동과 여성운동이 적극적으로 참 여한 반면 제 1 세대와 제 2 세대 종합 네트워크를 대표하는 Social Watch와 GCAP은 다소 소극 적이었다. Social Watch와 GCAP 모두 기본적으로 $\mathrm{OECD}$ 중심의 개발협력 논의에 비판적인 입장이었기에 부산총회에 큰 중요성을 부여하지 않았기 때문이다. ${ }^{16)}$

\section{표 3: 국제개발협력 분야의 글로벌 네트워크 비교}

\begin{tabular}{c|l|l|l}
\hline & \multicolumn{1}{|c|}{ 제1세대 } & \multicolumn{1}{c}{ 제2세대 } & \multicolumn{1}{c}{ 제3세대 } \\
\hline 시기와 계기 & $\begin{array}{l}\text { 1995 Copenhagen World } \\
\text { Summit for Social } \\
\text { Development (WSSD) }\end{array}$ & $\begin{array}{l}\text { 2000 Millennium Summit } \\
\text { 2005 Millennium } \\
\text { Summit+5 }\end{array}$ & $\begin{array}{l}\text { 2008 and 2011 OECD } \\
\text { High-level Forum on Aid } \\
\text { Effectiveness }\end{array}$ \\
\hline \begin{tabular}{c|l|l} 
대표적 \\
네트워크
\end{tabular} & Social Watch & $\begin{array}{l}\text { Global Call to Action } \\
\text { against Poverty (GCAP) }\end{array}$ & $\begin{array}{l}\text { BetterAid \& Open Forum for } \\
\text { CSO Development Effectiveness }\end{array}$ \\
\hline 홈페이지 & www.socialwatch.org & www.whiteband.org & www.betteraid.org \\
\hline 주요 & UN ECOSOC, UNDP & UN 총회, ECOSOC, UNDP & $\begin{array}{l}\text { OECD DAC Working Party } \\
\text { on Aid Effectiveness }\end{array}$ \\
\hline 주요 프레임과 & Social Development & $\begin{array}{l}\text { Millennium Development } \\
\text { Goals (MDGs) } \\
\text { Human Development }\end{array}$ & $\begin{array}{l}\text { Aid Effectiveness } \\
\text { Development Effectiveness }\end{array}$ \\
\hline 주요 활동 & $\begin{array}{l}\text { 시민사회의 대안적 개발 보고서 } \\
\text { 작성 }\end{array}$ & $\begin{array}{l}\text { MDGs 이행 감시 및 캠페인 } \\
\text { G8과 G20 대응 주도 }\end{array}$ & $\begin{array}{l}\text { 파리선언과 아크라행동강령의 } \\
\text { 히행 개발효과성 }\end{array}$ \\
\hline
\end{tabular}

16) BetterAid Coordinating Grop (BACG) 참여하고 있는 주요 단체는 ActionAid, ACT International Network, Femnet, Arrodad, ANND, APWLD, AWID International, CCIC, Care Int'I, CIVICUS Int'I Networks, CONCORD, Eurodad, IBIS, IBON, InterAction, ITUC, KoFID, LDC Watch, Social Watch, TI, Uganda National NGO forum, WIDE, Zimcodd 등이 있다. 조정그룹의 공동의장은 IBON Foundation/Reality of Aid 와 Association of Women's Rights in Development (AWID)가 담당해 왔다. 
제3세대의 대표적 네트워크인 BetterAid는 여러 측면에서 이전 세대의 네트워크와 차별성을 보이고 있으며 새로운 통합 네트워크 또한 극복해야 할 새로운 과제를 안고 있다.

먼저 이전 세대의 네트워크가 유엔을 중심으로 활동을 전개해 온 반면 BetterAid는 OECD를 주요 대상으로 활동해왔다. 이는 OECD가 2005년 원조효과성에 대한 파리선언을 채택하면서 국제개발협력 담론을 주도해왔기 때문이다. 국제시민사회 내부에서 경제 선진국으로 구성된 $\mathrm{OECD}$ 가 개발원조 문제를 주도하는 것의 정당성에 대한 문제제기가 있었지만 BetterAid는 전 략적 개입의 중요성에 동의하는 단체를 중심으로 활동을 전개하였다. 이러한 전략적 선택에 대 해 $\mathrm{OECD}$ 의 정당성 결핍을 해소에 이용당했다는 지적도 있었지만 글로벌 파트너십이 $\mathrm{OECD}$ 와 $\mathrm{UNDP}$ 의 공동운영으로 체제로 결정되면서 이러한 정당성 시비가 상당히 약화되었다.

둘째 BetterAid는 이전의 네트워크와 달리 아시아의 시민사회가 상대적으로 더 많은 리더십 을 행사하였다. 이는 BetterAid의 사무국을 필리핀의 IBON 재단이 담당하였고 BetterAid의 공동의장을 IBON 재단의 대표가 맡았기 때문이었다. Social Watch의 사무국은 우루구와이 몬테비데오 GCAP의 사무국은 남아공의 요하네스버그에 있어 자연스럽게 전자는 남미, 후자는 아프리카 시민사회의 영향력이 상대적으로 두드러졌다.

셋째, 조직적 측면에서 BetterAid는 글로벌한 개방적 플랫폼을 표방하였지만 Oxfam, World Vision, Save the Children 등 전통적인 개발단체를 적극적으로 견인하지 못하고 또 하나의 글로벌 플랫폼으로 작동했다는 지적이 있다. 비록 세부회의에서 BetterAid와 Open Forum이 단일 플랫폼으로 통합하기로 결정했지만 세부 회의에 참여하지 않은 많은 시민사회 단체가 참여할지는 여전히 미지수이다. 특히 앞서 지적했듯이 Social Watch와 GCAP 등 대표 적인 글로벌 네트워크의 소극적 참여로 새로운 통합 네트워크의 미래는 여전히 불투명하다고 할 수 있다. ${ }^{17)}$

넷째, BetterAid가 주창한 개발효과성 프레임의 효과성 또한 여전히 논란의 대상이다. 개발 효과성 개념의 불명확성과 이를 둘러싼 아전인수격 해석으로 인해 시민사회의 의도와 달리 개 발효과성 프레임이 개발을 역설적으로 양적인 성과 중심의 틀에 종속시키는 역효과가 발생하고 있다. 이와 관련하여 개발정의(Development Justice) 또는 인권의 핵심 가치인 인간존엄을 위

17) 부산총회에서 GCAP의 캠페인 구호와 연결하여 BetterAid for the World We Want란 슬로건을 채택했지만 정 작 GCAP은 부산총회에서 별다른 역할을 수행하지 못하였다. 
한 개발 (Development for Human Dignity) 등 보다 인권적 가치와 원칙에 부합하는 대안 프 레임의 필요성이 제기되고 있다. ${ }^{18)}$

다섯째 부산총회 이후 시민사회 캠페인의 의제 범위설정 문제이다. 새로운 네트워크는 의제를 너무 확대할 경우 선택과 집중의 효과가 약화되고 의제를 너무 좁힐 경우 효과성이 약화되는 문 제가 나타날 수 있다. 특히 확대할 경우 기존의 글로벌 네트워크와의 중복 또는 경쟁으로 인해 정당성 시비가 불거질 수 있다. 따라서 새로운 통합 네트워크의 성공은 기존의 글로벌 네트워크 와의 전략적 역할분담을 통해 효과적인 상호 보완적 파트너십을 형성하느냐에 달려있다고 보여 진다.

\section{3) 부산총회 이후 국제개발 관련 회의와 시민사회의 대응}

2005년 파리와 2008년 아크라가 원조효과성에 초점을 맞추었다면 부산 총회는 의제 측면에 서 원조효과성 논의를 개발효과성으로 확대하는 계기가 되었다. 즉 원조에 대한 기술적 논의를 보다 정치적인 담론으로 확산하는 계기로 작용하였다. 따라서 부산 이후 개발원조 또는 국제개 발협력의 의제는 좁은 의미의 원조를 넘어 개발 패더라딤에 대한 담론으로 확대되었다. 따라서 부산총회에서 합의된 효과적인 개발협력을 위한 글로벌 파트너십(GFEDC)은 원조를 넘어 국제 개발의 담론 및 정책을 직간접적으로 다룰 예정이다. 따라서 부산 총회 이후 국제시민사회는 자 연스럽게 국제개발 및 국제개발협력와 직간접적인 관련된 의제를 다루는 주요 국제회의를 부산 총회 후속 이행의 관점에서 적극적으로 참여하고 있다. 현재 예상되는 주요 회의로는 유엔 경제 사회이사회의 개발협력포럼(DCF), G20 정상회의의 개발의제, 2012년 6월 브라질 리우에서 열 리는 지속가능발전유엔회의(UNCSD), 2015년 MDGs 이후 국제개발목표를 다시 만드는 유엔 총회의 고위급회의를 들 수 있다.

첫째, 2001부터 2015년까지 15년 기한으로 출발한 MDGs 캠페인 반환점에 해당하는 2008 년 출범한 유엔 경제사회이사회의 개발협력포럼은 2010년에 이어 2012년 7월 뉴욕에서 세번째 포럼을 개최할 예정이다. 개발협력 특히 MDGs 이행관련 유엔의 대표적 기구인 이 포럼은 대표 성은 있지만 자체 집행기구를 가지고 있지 않아 실효성 측면에서 취약하다는 평가를 받아왔다. 그러나 부산 총회 결과 이행의 사무국 역할을 UNDP와 $\mathrm{OECD}$ 공통으로 운영하기로 함에 따라

18) 이와 관련하여 국제 앰네스티의 사회권 관련 Demand Dignity 캠페인과 Oxfam의 Demanding Justice 캠페인 프레임을 참조할 필요가 있다. 
이 개발협력포럼이 수행할 국제개발협력 관련 정책 조정 역할에 관심이 모아지고 있다.

둘째는 G20 개발실무분과이다. 2010년 서울 G20 정상회의를 계기로 출범한 개발실무분과 의 계획이 2011년 프랑스 칸 정상회의에 제출되었고 2012년 6월 멕시코 회의에서는 보다 구체 화될 예정이다. 부산총회의 문서에 G20이 직접 언급되지는 않았지만 의제의 내용과 방향성을 고려할 때 글로벌파트너십과의 다각적 협력이 예상된다.

셋째 리우 +20 은 국제개발협력의 새로운 의제와 목표와 관련하여 주목을 받고 있다. 리우 +20 준비과정에서 한국을 비롯하여 $\mathrm{OECD}$ 국가가 새로운 성장동력으로 주장하는 녹색경제와 개도국이 선호 및 지지하는 지속가능발전 패러다임을 둘러싸고 적지 않은 긴장과 논쟁이 전개 되고 있다. 그리고 콜롬비아 정부가 제안한 지속가능발전목표(Sustainable Development Goals, SDGs)이 2015년 이후 MDG의 대안이 될 수 있는지에 대한 다양한 의견을 표출되고 있다.

마지막으로 작년 12월 유엔에서 본격적으로 논의를 시작한 2015년 MDGs 이후의 개발의제 에 대한 논의이다. 2010년 유엔 총회는 2013년 고위급회의를 통해 2015년 이후 MDGs를 대 치할 국제개발목표에 대한 결정을 하기로 하였다. 따라서 기존의 MDGs 이행에 대한 평가와 함 께 지금까지 드러난 MDGs의 한계를 보완하는 작업을 본격적으로 추진하고 있다.

부산총회의 이행을 담당하는 글로벌 파트너십 구성 논의는 올해 6월까지 마무리되지만 부산 파트너십의 내용 이행 관련 논의는 앞서 언급한 주요 국제회의를 거치면서 구체화될 것으로 보 인다. 따라서 올해 9 월 출범한 새로운 네트워크는 이러한 국제회의에 효과적인 개발협력의 관 점에서 적극적으로 개입할 것으로 예상된다.

표 4: 부산총회 전후의 국제개발 관련 주요 회의

\begin{tabular}{c|l|l|l}
\hline $\begin{array}{c}\text { 시간과 장소 } \\
\begin{array}{c}\text { 2010년 11월 } \\
\text { 서울 }\end{array}\end{array}$ & G20 회의 & \multicolumn{1}{|c}{ 주상회의 의제 } & 관련 국제시민사회 단체 \\
\hline $\begin{array}{c}\text { 2011년 5월 } \\
\text { 이스탄불 }\end{array}$ & $\begin{array}{l}\text { 제4차 최빈귱(LDC위기 해소와 개발 } \\
\text { 정상회의 }\end{array}$ & $\begin{array}{l}\text { 시민사회 G8 \& G20 } \\
\text { Working Group }\end{array}$ \\
\hline $\begin{array}{c}\text { 2011년 11월 } \\
\text { 칸 }\end{array}$ & G20 정상회의 & $\begin{array}{l}\text { 경젹에의 빈곤퇴치 해소, } \\
\text { 금융거래세(FTT) }\end{array}$ & $\begin{array}{l}\text { G8 \& G20 Working } \\
\text { Group }\end{array}$ \\
\hline $\begin{array}{c}\text { 2011년 11월 } \\
\text { 부산 }\end{array}$ & $\begin{array}{l}\text { OECD 부산 } \\
\text { 세계개발원조총회 }\end{array}$ & $\begin{array}{l}\text { 원조효과성과 } \\
\text { 효과적인 개발협력 } \\
\text { (개발효과성) }\end{array}$ & $\begin{array}{l}\text { BetterAid와 Open } \\
\text { Forum 등 }\end{array}$ \\
\hline
\end{tabular}




\begin{tabular}{c|l|l|l}
\hline 시간과 장소 & \multicolumn{1}{|c|}{ 회의 } & \multicolumn{1}{|c|}{ 주요 의제 } & 관련 국제시민사회 단체 \\
\hline $\begin{array}{c}\text { 2010년 } \\
\text { 6월 리우 }\end{array}$ & $\begin{array}{l}\text { UN 지속가능개발회의 } \\
\text { (리우+20) }\end{array}$ & $\begin{array}{l}\text { 녹색ㄱㅕㅕ제와 지속가능발전 } \\
\text { 지속가능발전목표(SDG) }\end{array}$ & $\begin{array}{l}\text { 국가별 지역별 Rio+20 } \\
\text { 대응 네트워크 }\end{array}$ \\
\hline $\begin{array}{c}\text { 2012년 } \\
\text { 6월 멕시코 }\end{array}$ & G20 정상회의 & 금융위기 해소, 녹색성장 & $\begin{array}{l}\text { G8 \& G20 Working } \\
\text { Group }\end{array}$ \\
\hline $\begin{array}{c}\text { 2012년 } \\
\text { 7월 뉴욕 }\end{array}$ & $\begin{array}{l}\text { UN ECOSOC } \\
\text { 개발협력포럼 }\end{array}$ & MDGs 이행 & $\begin{array}{l}\text { Social Watch, } \\
\text { ActionAid, CIVICUS 등 }\end{array}$ \\
\hline $\begin{array}{c}\text { 2013년 } \\
\text { 9월 뉴욕 }\end{array}$ & $\begin{array}{l}\text { UN High-level } \\
\text { Plenary }\end{array}$ & 2015년 이후의 MDGs & GCAP, Beyond 2015 등 \\
\hline
\end{tabular}

\section{4. 부산 세계개발원조총회와 한국 시민사회}

앞서 언급했듯이 부산 세계시민사회포럼(BCSF)와 부산 세계개발원조총회의 '성공적' 개최는 한국 시민사회에 역사적 기회이자 도전이었다. 부산총회를 계기로 한국정부와 시민사회는 국제 개발협력 분야의 '후발주자' 에서 중요한 행위자로 등장하였다. 그만큼 효과적인 국제개발협력 관련 국제사회의 담론, 정책과 실행 모든 분야에서 한국에 대한 기대는 높아졌다. 이에 따라 한 국정부와 시민사회의 국제사회에 대한 책임의식 또한 높아졌다. 그러나 투명성 등 국제적인 비 교평가에서 한국 원조의 질은 최하위를 기록하고 있고 한국의 시민사회의 개발원조 사업의 질 과 효과성에 대한 논란이 점차 국내외에서 높아지고 있다. 부산총회 주최 국가의 화려한 위상 이면에 감추어진 부끄러운 자화상이다. 한국정부는 부산총회 결과 이행과정에서 이러한 대외적 이미지와 현실 사이의 격차를 줄이는데 최선을 다해야 한다. 한국의 시민사회 또한 예외는 아니 다. 한국 정부의 $\mathrm{ODA}$ 사업 뿐 아니라 한국 시민사회의 개발원조 사업에 대한 논란 또한 점증하 고 있기 때문이다.

부산총회는 개발협력 분야 시민사회 운동과 네트워크에서 새로운 전환의 계기를 제공하였다. 90년대까지 한국의 개발 $\mathrm{NGO}$ 는 개별 단체 차원에서 사업을 수행해 왔고 양적 증대에 주력하 였다. 그러나 1996년 OECD 가입을 계기로 1999년 한국해외원조단체협의회 (해원협)가 창립되 고 2005년에는 지구촌빈곤퇴치시민네트워크 (GCAP Korea) 그리고 2010년에는 국제개발협 력시민사회포럼 (KoFID)이 출범하였다. 
80여개의 현장 사업 단체가 주축인 해원협이 네트워크 기반조직(플랫폼)이라면 20여개의 단 체로 구성된 GCAP Korea와 KoFID는 애드보커시 중심의 우산 조직에 해당된다. 19) 즉 해원협 이 회원단체의 공통 이해를 대변하고 회원단체의 역량강화와 공동사업을 조정하는데 주력하는 데 반해 GCAP Korea와 KoFID는 각각 새천년개발목표(MDGs)와 G20 정상회의 그리고 $\mathrm{OECE} \mathrm{DAC}$ 의 원조효과성과 개발효과성 그리고 부산총회 이후에는 리우+20을 계기로 지속가 능개발과 $\mathrm{MDG}$ 이후의 개발의제와 목표로 의제를 확장하고 있다. 이중 가장 최근에 출범한 $\mathrm{KoFID}$ 는 해원협의 현장서비스 단체와 애드보커시 단체의 결합체로 부산총회와 부산 세계시민 사회포럼 행사를 치루면서 대정부 정책 애드보커시와 국제 시민사회와의 대표적인 창구로 자리 를 잡아가고 있다. ${ }^{20)}$

부산총회를 약 1 년 앞두고 출범한 $\mathrm{KoFID}$ 는 한국의 시민사회를 대표하여 BetterAid와 Open Forum에 적극참여하였고 부산총회 이후에도 지속적인 협력 관계를 유지하고 있다. 부산파트 너십의 좁은 의미의 원조효과성에서 넓은 의미의 효과적인 개발협력으로 의제를 확대하면서 $\mathrm{KoFID}$ 도 국제시민사회와 발 맞추어 다루는 의제 영역을 확대하고 있다.

\section{5. 한국 시민사회단체의 개발효과성 증진을 위한 제안}

부산총회를 계기로 한국정부와 시민사회는 국제개발협력 분야의 '후발주자' 에서 중요한 행위

19) 시민사회의 네트워크 또는 연대조직 (coalition or alliance-building)은 크게 기반조직 (platform)과 우산 조직 (umbrella)로 구분할 수 있다. 전자는 회원단체 조직의 공통 이해를 기반으로 구성되며 장기적이고 안정적인 반 면 후자는 참가 단체가 공동으로 추구하는 가치를 실현하는 애드보커시 중심으로 구성되며 한시적이고 기동성을 특성으로 한다. 전자는 실무력을 갖춘 사무국이 정례적인 사업 수행에 중추적 역할을 하는데 반해 후자는 최소 한의 사무국 조직으로 참가 단체의 역량을 최대한 활용한 캠페인을 수행한다. 전자는 플랫폼이 상징하듯이 회원 단체(train)과 사업영역(track)이 계속 추가될 수 있는 반면 후자는 우산이 상징하듯 외부 환경(날씨)의 변화에 따 라 수시로 접거나 펼칠 수 있다. 우산조직에서는 사무국 보다 어느 단체가 주도하느냐, 즉 우산대를 누가 잡느냐 그리고 우산의 크기가 중요하게 간주된다. 우산 조직은 특정 캠페인을 종료하는 경우 해산하거나 보다 안정적인 플랫폼 조직으로 전화하는 경우도 있다. 국내에서 전자의 대표적 조직으로는 해원협을 후자는 GCAP Korea와 $\mathrm{KoFID}$ 를 들 수 있다.

20) KoFID에는 2012년 3월 현재 굿네이버스, 기후변화연구소, 세이브더칠드런, 아시안브릿지, 아시아재단, 앰네스 티코리아, 어린이재단, 월드비전한국, 월드투게더, 유엔인권정책센터, 인구보건복지협회 지구촌나눔운동, 참여연 대, 코피온, 하트하트재단, 한국여성단체연합, 한마음한몸운동본부, 한국에이즈퇴치연맹, 한국인권재단, 한국 YMCA전국연맹, ODA Watch, 한국해외원조단체협의회, 한국국제개발협력학회가 회원단체로 참여하고 있다. 
자로 등장하였다. 그만큼 효과적인 국제개발협력 관련 국제사회의 담론, 정책과 실행 모든 분야 에서 한국에 대한 기대는 높아졌고 이에 따라 한국정부와 시민사회의 국제사회에 대한 책임의 식 또한 높아졌다. 그러나 투명성 등 국제적인 비교평가에서 한국 원조의 질은 최하위를 기록하 고 있고 21 한국의 시민사회의 개발원조 사업의 질과 효과성에 대한 논란이 국내외에서 높아지고 있다. 부산총회의 성공적 주최 국가라는 화려한 위상 이면에 감추어진 부끄러운 자화상이다. 부산총회 주최국가로서 한국 정부와 시민사회는 수 년 후 부산 파트너십 이행을 평가할 때 모범 적인 국가로 인정받을 수 있도록 지금부터 체계적인 노력을 할 필요가 있다.

부산총회 이후 시민사회의 역할과 과제와 관련하여 크게 시민사회 자체와 이해관계자 (stake-holders) 그리고 정부 관련 역할과 과제를 국내와 국제로 구분하여 제시하고자 한다.

\section{1) 시민사회의 국내적 과제와 역할}

먼저 시민사회는 국내적으로 대중화와 전문화를 통한 국제개발협력 사업의 질과 효과성을 높 이는데 주력할 필요가 있다. 이와 관련하여 구체적으로 시민사회는 이스탄불 원칙과 시엠림 프 레임워크의 모범적 실행, 인권에 기반한 접근(RBA)의 적극적 도입 및 실행, 중간 리더십 역량 강화, 농민, 여성단체 및 노동조합의 참여 확대, 세계시민교육의 확산과 효과성 제고 등을 강조 하고자 한다.

가) 이스탄불 원칙 실행

앞에서 언급했듯이 이스탄불 원칙의 인정은 시민사회 관점에서 볼 때 부산총회의 가장 중요한 성과로 꼽히고 있다. 이제 시민사회는 지난 3년간 스스로의 노력으로 만든 이스탄불 원칙과 국 제 프레임워크를 충실히 실행하여 시민사회의 개발 효과성을 증진하는 과제를 떠안게 되었다. 그동안 한국의 개발원조 단체는 자체로 만든 윤리적 기준과 사업 지침 또는 관련 또는 소속된 국제 단체의 원칙에 따라 독자적인 사업을 수행해왔다. 그러나 이제는 국내와 국제 모두 공통된 시민사회의 원칙이 수립되어 시민사회의 개발효과성을 평가할 수 있는 기반이 마련되었다. 한 국 시민사회의 해외 개발사업이 양적으로 급증하면서 최근 사업 추진 방식의 윤리성과 효과성

21) [세계일보] 국격 높이기 헛물만? $\cdots$ 대외원조 4년째 '꼴찌' (12.02.06)

미국 싱크탱크 '세계개발센터(CGD)' 가 최근 발표한 '2011년도 개발공헌지수(CDI)' 보고서에 따르면 우리나라는 조사 대상 22개국 중 최하위를 기록했다. 이 조사에 한국이 포함된 2008년 이래 4년 연속 종합 꼴찌다. 기사출처: http://www.segye.com/Articles/NEWS/ECONOMY/Article.asp?aid=20120206004604\&subctg1=\&subctg2= 
을 둘러싼 논란이 곳곳에서 불거졌지만 이를 객관적으로 조사 평가하고 개선하는 기준이 부재 해 어려움이 적지 않았다. 이스탄불 원칙을 만드는 과정에 적극 참여하였고 부산총회 주최국의 시민사회로서 모범적인 사례를 만들어 공유할 필요가 있다.

일단 부산 세계시민사회포럼 참가 단체 특히 KoFID의 회원단체 중심으로 이스탄불 원칙을 실천하는 노력이 필요하다. 최근 논란이 되고 있는 새마을운동 또는 '한국형 개발경험 전수' 프 로그램도 이번 기회에 이스탄불 원칙에 입각하여 비판적으로 조명하여 국제 기준과의 조화 또 는 부합하도록 개선할 필요가 있다. 한편 $\mathrm{KOICA}$ 는 시민사회 협력 사업 선정 및 평가지표에 이스탄불 원칙을 반영하여 부산파트너십의 이행에 적극 기여할 필요가 있다.

나) 인권에 기반한 접근 (Rights-based approach (RBA))

부산총회는 아크라에 이어 인권을 국제개발협력의 중요한 원칙이자 목표로 재강조했지만 이 를 시행하는 구체적 정책적 도구 즉 인권에 기반한 접근(RBA)를 공식화 하는 데까지 이르지는 못했다. 그러나 막판 협상에서 제 22 항의 시민사회 역할에 RBA가 포함되어 부분적이지만 RBA 는 부산파트너십에서 시민사회의 중요한 역할로 인정받았다. BetterAid는 처음부터 RBA를 원 조의 효과성을 높이고 원조가 개발효과성으로 이어지는데 중요한 정책 도구로 인식하고 시종일 관 강하게 주장하였다. 비록 Building Block에 포함되지는 못했지만 RBA는 부산총회 기간 중 부대행사에서 중요한 이슈로 다루어졌다. ${ }^{22)}$

국내에서 보수와 진보의 정치적 이념으로 간주되는 현실과 달리 국제사회 특히 UN 그리고 $\mathrm{OECD}$ 에서도 인권은 국제개발협력의 기본 원칙이자 목표이고 개발협력 분야의 인권주류화 (mainstreaming)는 중요한 정책과제로 다루어지고 있다. ${ }^{23)}$ 유엔의 인권기구가 개발관련 규 범적 기준을 제공하는 역할을 하는데 반해 유엔의 개발관련 기구는 인권 특히 경제사회적 권리 분야에서 구체적으로 실행하는 역할을 한다. 따라서 유엔에서 인권과 개발분야의 협력은 보편 적 규범의 확산과 실현이라는 측면에서 매우 중요하게 인식되고 있다.

22) 케냐 출신의 Maini Kiai 유엔 집회결사의 자유 특별보고관은 부산 세계개발원조총회의 기조연설자로 초청받았고 부산총회 기간 중 부대행사로 열린 RBA 세션의 패널로 참석하였다. 이 RBA 부대행사의 논의를 토대로 BetterAid는 여러 단체는 UNDP, 스웨덴의 국제개발청(SIDA) 등과 함께 RBA를 Building Block으로 만들기로 하고 세부 회의에서 RBA 실무분과를 구성하였다.

23) 올해 2월 28일 유엔 인권이사회는 인권주류화와 국제협력을 주체로 특별 패널을 개최하여 세계은행, UNDP, $\mathrm{WHO}, \mathrm{ILO}, \mathrm{UNICEF}$ 등 국제기구가 개발정책과 사업에 인권을 어떻게 반영하고 있는지 토론하였다. 필레인 유 엔인권최고대표는 모두 연설에서 각종 인권조약 기구의 권고안과 국가별 인권상황 정기검토 (UPR)의 권고안을 국가별 발전목표와 정책에 포함하는 것이 중요하다는 점을 강조하였다. 
이미 Oxfam, 세이브더칠드런, 월드비전 등 주요 국제개발 시민사회단체는 이미 인권을 사업 실행에서 $\mathrm{RBA}$ 를 적용하고 있고 다양한 성공 사례가 보고되고 있다. 국내에서도 이러한 영향을 받아 점차 $\mathrm{RBA}$ 의 중요성과 필요성에 대한 인식이 높아지고 있고 $\mathrm{RBA}$ 적용 사례도 점차 늘어 나고 있다. ${ }^{24)}$ 부산총회 이후 한국의 시민사회는 이스탄불 원칙 시행과 함께 RBA를 전면적으 로 도입하여 시민사회의 개발효과성 증진에 적극 활용할 필요가 있다.

구체적으로 현재 진행되고 있는 다양한 개발원조 사업을 $\mathrm{RBA}$ 의 관점에서 평가하고 성공과 실패 사례를 공유할 필요가 있다. 이를 통해 $\mathrm{RBA}$ 가 단순한 이론과 원칙이 아니라 현장 사업에 서 요긴한 도구라는 인식이 보다 넓게 확산될 필요가 있다. $\mathrm{KOICA}$ 의 ODA 교육원에서도 국제 개발협력과 인권 그리고 $\mathrm{RBA}$ 관련 교재를 개발하고 정규 커리큘럼에 포함시키고 민관협력실은 시민사회내의 RBA 보급을 부산파트너십의 주요 사업으로 설정할 필요가 있다.

다) 노동, 농민 및 여성운동의 참여

효과적인 개발협력을 위해서는 노동, 여성, 농민운동의 참여를 강화할 필요가 있다. 대부분의 개발협력이 개도국의 농촌지역에서 이루어지고 농촌지역에서 여성의 역할을 고려할 때 여성단 체와 농민단체의 참여가 매우 중요하다. 특히 새마을운동을 전략적으로 한국형 개발원조의 대 표적인 '수출상품' 으로 홍보되고 있음을 고려할 때 이에 대한 농민운동의 비판적 개입이 요구 된다. 노동조합 또한 $\mathrm{ODA}$ 를 국제연대의 수단으로 적극활용할 수 있어야 한다. 잘 알려졌듯이 부산총회는 노동조합을 중요한 개발 행위자로 인정하였고 양질의 일자리(decent work)가 개발 협력의 주요 목표로 설정되었다. ${ }^{25)}$ 개도국으로 진출하는 한국 기업의 수가 증대하고 정부, 기 업 및 시민사회의 삼각협력을 강조하는 민관협력(Public Private Partnership)이 강조되는 최 근의 추세에 비추어 볼 때 노동조합의 적극적 참여가 필요하다.

24) 한국인권재단은 RBA 관련하여 작년 기업과 개발협력, 유엔 RBA 자료 강독, RBA 전문가 워크샵 등을 통하여 부산총회를 앞두고 한국시민사회내에 RBA의 확산하려는 노력을 전개하였지만 개발협력 시민사회 전체로 확산 되려면 보다 체계적인 노력이 필요하다.

25) 부산최종 문서는 22항의 시민사회단체 처럼 별도의 조항이 없어지만 제3항에서 양질의 일자리(decent work)가 개도국에서 강하고 지속가능한 동반성장과 함께 개발협력의 목표로 명시되었고 제11항에서 인권, 성평등, 환경적 지속가능성 및 장애와 함께 양질의 일자리가 공통의 원칙으로 언급되었다. 그리고 민간기업(private sector)를 다룬 제32항에서 노동조합을 기업과 함께 개발의 중요한 행위자로 인정하였다. 이렇듯 양질의 일자리는 부산총 회에서 처음으로 $\mathrm{OECD}$ 의 개발효과성 담론에 공식 의제로 포함되었고 자연스럽게 노동조합은 개발협력의 중요 한 행위자로 인정받게 되었다. (이성훈, "시민사회가 바라보는 부산총회의 성과와 향후 과제" 국제개발협력 (2011, No 4), 한국국제협력단 
라) 국제개발 리더십 강화

부산총회에 대한 집단적 참여경험을 계기로 많은 청년 활동가가 국제 개발담론과 연대의 현장 을 직접 경험하였다. 이를 통해서 한국 시민사회의 현주소를 파악하고 향후 어떻게 개선해야 할 지에 대한 공감대가 조성되었다. 이러한 소중한 경험이 한번의 사건으로 머물지 않고 시민사회 의 지도력 강화로 이어지기 위해서는 보다 체계적인 리더십 양성을 위한 노력이 요구된다. 국제 개발협력 분야 시민사회의 리더십은 전환기를 맞이하고 있다. 과거 기독교에 기반한 선교와 자 선복지 사업 중심에서 다종교, 시민사회, 기업 경영자, 외교관 등 다양한 배경의 리더가 현재 시 민사회를 이끌어 나가고 있다.

그러나 대부분의 단체는 허리에 해당하는 30대 40대의 중간 리더십이 매우 취약한 구조를 가 지고 있다. 최근 한국의 $\mathrm{OECD} \mathrm{DAC} \mathrm{가입에} \mathrm{따른} \mathrm{원조금액} \mathrm{증대와} \mathrm{한비야} \mathrm{또는} \mathrm{반기문} \mathrm{영향으}$ 로 많은 청년이 국제개발협력 분야에 관심을 가지고 참여하여 저변은 확대되고 있지만 풍부한 해외 현장경험과 이론으로 무장한 중간층 지도력이 여전히 취약하다. 생계를 꾸려나가기에 턱 없이 낮은 임금 체계와 보수적이고 폐쇄적인 조직문화와 전문가 양성에 대한 투자 부족 등으로 인해 중장기적 비전을 가지고 지속적인 헌신을 할 수 있는 환경이 조성되어 있지 않아 이직률이 매우 높은 것으로 알려져 있다.

과거의 시민사회 지도자 대부분이 자수성가형 이었다면 미래의 리더는 체계적인 투자와 훈련 을 통해 양성해야 한다. 개별 단체 차원에서 힘들다면 공동의 기금을 마련하여 재충전과 필요한 역량배양 프로그램 참여를 활성화하는 것을 고려해 볼 수 있다. 대학에서의 개발협력 인지강화 프로그램을 통한 대중적 확산도 중요하지만 이미 개발협력 분야에 투신한 활동가를 전문성을 겸비한 리더로 양성하는 것은 한국 시민사회가 국제사회에서 보다 큰 기여를 하는데 필수적인 요건이기도 하다. 이를 위해서는 현재 $\mathrm{ODA}$ 연구원과 대학 중심의 강의 위주 ODA 이해 확산 교육을 넘어 현장경험과 전문적 지식을 겸비한 지도력을 양성하는 프로그램을 체계적으로 만들 어 시행할 필요가 있다.

\section{2) 한국 시민사회의 국제적 과제와 역할}

국제적 차원에서 한국 시민사회의 역할 강화 관련하여서는 전문가 양성, 아시아 연대 강화, 국제연대 체계 정비 등 몇 가지 과제를 제시하고자 한다.

가) 국제 정책 애드보커시 전문가 양성 
부산 총회를 통해 경험했듯이 한국 시민사회에 국제 정책 애드보커시 전문가의 수가 절대적으 로 부족하다. 국내도 마찬가지이지만 개발분야의 전문가는 오랜 시간이 걸리는, 단순히 해외에 서 박사학위를 취득했거나 외국어를 잘한다고 또는 해외에서 봉사활동을 했다고 해서 자동적으 로 국제 애드보커시 전문가의 역할을 하는 것은 아니다. 국제 개발현장에 대한 이해, 전문적 지 식, 중장기적 비전과 헌신, 애드보커시 관련 기술을 갖출 것이 요구된다. 규모가 작은 단체는 힘 들겠지만 어느 정도의 규모를 갖춘 시민사회단체는 지금부터라도 중장기 계획을 세워 체계적으 로 전문가를 양성하는 프로그램을 실시할 필요가 있다. 이를 위해서는 $\mathrm{KOICA}$ 등 정부기관의 지원과 협력 또한 매우 중요하다.

구체적으로 현장사업 중심의 기존 $\mathrm{KOICA}$ 나 해원협의 해외봉사단을 정책 애드보커시 분야로 확대할 필요가 있다. 예를 들어 미국의 워싱턴에 소재한 InterAction 또는 프랑스 파리의 CoordinationSud, 브루셀의 CONCORD 등 세계은행, $\mathrm{OECD}, \mathrm{EU}$ 등 개발협력 관련 국제기 구가 위치한 도시의 시민사회연대조직에 파견을 하여 현장경험을 쌓게 하고 이를 국내의 국제 연대 활동에 적극적으로 활용할 필요가 있다.

정책 애드보커시 분야는 현장 경험에 바탕한 전문적인 지식을 필요로 하기에 시민사회 내에 대안적인 개발 담론과 정책을 생산하는 조사연구 및 애드보커시 전담 단체를 전략적으로 강화 하는 것이 매우 중요하다. 기업이 연구개발 (R\&D, Research \& Development)에 많은 투자 를 하듯이 시민사회도 이제는 연구와 애드보커시 R\&A(Research and Advocacy)에 중장기적 비전을 갖고 보다 많은 투자를 할 필요가 있다. ${ }^{26)}$

나) 일국적 플랫폼 중심의 국제 네트워크 강화

Global Light, Country Heavy란 구호가 상징하듯이 부산총회 결과의 이행에서 각국 정부 는 핵심적 역할을 한다. 따라서 부산총회 결과 이행에서 일국적 차원의 시민사회 정책 애드보커 시 역할이 중요하다. 나라마다 편차가 있지만 대부분의 공여국과 개도국에 개발협력 관련 플랫 폼이 활동하고 있고 상당수의 대표가 부산총회에 참여했다. ${ }^{27)}$ 국제 시민사회 네트워크가 특정

26) 현재 한국의 시민사회에 애드보커시 전문 단체로 ODA Watch, 조사연구 단체로는 글로벌발전원구원(REDI)이 활동하고 있다. 최근 이대, 경희대 등 여러 대학에 조사연구 및 교육센터가 활발한 활동을 하고 있다. 월드비전, 굿네이버스, 세이브더칠드런 등이 조직내에 애드보커시 기능을 강화하고 있고 참여연대 또한 ODA 정책 감시활 동의 일환으로 모니터 보고서와 대안 정책보고서를 발간하고 있다. 그러나 대부분이 영세한 규모이고 국내 이슈 중심이어서 최근 다채롭게 전개되는 국제 개발담론과 정책을 모니터하고 한국의 경험에 바탕한 정책적 의견을 제시하는데 까지 이르지는 못하고 있다. 
주제나 영역을 중심으로 구성되는데 반해 일국적 차원의 플랫폼은 다주제, 다영역으로 구성되 어 있다. 따라서 다양한 국제 네트워크에 가입 및 협력하에 국제 캠페인에 참여하고 있다. 그러 나 지난 10 여년간 다양한 국내적 현실을 충분히 반영하지 않은 채 몇몇 국제단체 중심으로 국 제회의의 대응 체계가 만들어지면서 국내 현실과 사업과의 연관성 부족이라는 문제가 나타나고 있다. 따라서 부산 총회 이후에는 일국적 플랫폼의 수평적 연대를 강화하여 아래로부터의 국제 연대를 강화할 필요가 있다. ${ }^{28)}$

이와 관련하여 일단 한국의 개발원조 사업에서 중요한 위치를 차지하는 국가의 일국적 플랫폼 과 양자간 연대를 강화하고 이를 확대 또는 동시에 아시아와 아프리카의 일국적 플랫폼과의 연 대를 강화할 필요가 있다. 특히 부산총회 주최국의 시민사회로서 현지 국가의 시민사회에 부산 총회 결과를 알리고 함께 시행하는 사업 모델을 만드는 것을 고려해 볼 수 있다. 더 나아가 현 지 국가의 플랫폼과 함께 한국정부의 개발원조 사업 평가를 공동으로 수행해 볼 수 있다.

\section{다) 효과적 국제연대를 위한 국내적 연대와 협력 강화}

현재 국내의 국제개발협력 분야 시민사회는 다양한 배경을 가진 단체로 구성되어 있다. ${ }^{29)}$ 국 제연대 관련해서는 월드비전이나 세이브더칠드런 처럼 국제 네트워크 체계 속에서 사업을 수행 하는 단체가 있고 굿네이버스나 정토회 처럼 한국이 국제본부 역할을 하는 단체도 있다. 개별 단체가 아니라 연대조직 형식으로 국제연대 사업을 수행하는 협의체로는 현재 한국해외원조협 의회(해원협), 지구촌빈곤퇴치시민네트워크(GCAP Korea), 국제개발협력시민사회포럼 (KoFID)가 대표적이다. 앞에서 언급한 제2세대의 GCAP과 제3세대의 BetterAid에는 GCAP Korea ${ }^{30)}$ 와 KoFID가 참여하고 있고 제1세대의 Social Watch에는 경실련이 회원단체로 참여 하고 있다. 원조를 감시하고 보고서를 발간하는 Reality of Aid (RoA)에는 참여연대와 ODA

27) 한국해외원조단체협의회(해원협)은 부산 세계시민사회포럼 기간 중 International Platform of National

Platforms (IFP) 소속 약 50 여개국의 일국적 플랫폼 대표를 초청해 서로의 활동을 소개하는 만찬을 조직하였

다. 해원협은 현재 IPF에 정식 가입을 추진 중이다.

28) 필자는 이런 아래로부터의 패러다임과 관련하여 세부 회의에서 Locally rooted, nationally initiated, regionally coordinated and globally facilitated란 틀을 제시하였다.

29) 1999 년에 출범하여 현재 86 개의 회원단체가 가입해있는 한국해외원조협의회(해원협)는 한국의 대표적인 일국적 플랫폼이다. 이외에도 해원협에 속하지 않으면서 독자적으로 또는 KOICA 협력사업을 수행하는 단체까지 포함하 면 국내의 국제개발협력 단체 수는 200여개에 달하는 것으로 추정하고 있다. 이러한 단체는 국내의 개발 및 복 지사업과 국제개발협력을 동시에 하는지 아니면 국제개발협력만을 전문으로 하는지, 국제개발협력만을 전문으로 하는지 아니면 다양한 이슈의 하나로 다루고 있는지, 현장사업 중심 (service delivery) 또는 애드보커시 중심 그리고 이 두 가지를 함께 하는지 등 다양한 기준으로 구분할 수 있다.

30) 지구촌빈곤퇴치시민네트워크는 약어로 지빈퇴로 불러왔는데 어감의 문제가 있어 최근 약어를 GCAP Korea로 부르기로 결정하였다. 
Watch 그리고 지구적 차원의 시민사회 참여를 증진하고 조정하는 역할을 하는 CIVICUS에는 참여연대가 참여하고 있다. 한편 해외 개발원조사업 단체를 중심으로 구성된 해원협은 GCAP Korea와 KoFID에서 운영위원장 역할을 수행하고 있으며 일국적 플랫폼의 네트워크인 IFP에 가입을 추진하고 있다.

부산총회를 계기로 개발효과성 의제가 부각되면서 원조를 기술적 이슈가 아닌 가난퇴치를 위 한 MDGs, 불평등, 개발재원의 다양화, 경제개발 패러다임 등 국제 정치경제 구조 영역으로 국 제개발협력의 의제가 확산되었다. 따라서 효과적인 개발협력을 위한 글로벌 파트너십 (GPEDC)은 전통적인 $\mathrm{OECD}$ 개발원조위원회(DAC)와 다자간개발은행 $(\mathrm{MDB})$ 이외에도 UNDP, 유엔 경제사회이사회의 개발협력포럼(DCF), G20 개발실무분과(DWG) 등과의 협력이 강조되고 있다.

따라서 국제 시민사회내에서 제 1 세대, 제 2 세대, 제 3 세대 국제 네트워크간의 보다 효과적인 협력이 그 어느 때보다 요구되고 있다. 이는 국내에서 마찬가지 이다. 각 협의체가 다루고 있는 의제와 역할을 종합적으로 재점검하여 정보와 전략의 공유 및 효과적인 협력 체계를 만들필요 가 있다. 특히 사무국의 취약한 실무역량과 중복되는 회원체계를 고려할 때 자원의 효과적 배분 을 위해서라도 국제연대를 위한 국내연대 체계를 정비할 필요가 있다.

\section{표 5: 국제 시민사회 네트워크와 한국의 회원 및 관련 단체}

\begin{tabular}{l|l}
\hline \multicolumn{1}{c|}{ 주요 국제 네트워크 } & \multicolumn{1}{c}{ 한국의 회원 및 관련 단체 } \\
\hline Social Watch & 경실련(CCEJ) \\
\hline Global Call to Action against Poverty (GCAP) & 지구촌빈곤퇴치시민연대(GCAP-Korea) \\
\hline BetterAid & 국제개발협력시민사회포럼(KoFID) \\
\hline Open Forum for CSOs Development Effectiveness & 국제개발협력시민사회포럼(KoFID) \\
\hline Reality of Aid (ROA) & ODA Watch, 참여연대(PSPD) \\
\hline CIVICUS & 참여연대(PSPD) \\
\hline International Forum of National Platforms(IFP) & 한국해외원조단체협의회(해원협, KCOC) 가입 예정 \\
\hline
\end{tabular}

\section{3) 이해관계자와의 비판적 협력 과제와 역할}

앞에서 언급했듯이 부산총회는 이전과 달리 정부 뿐만 아니라 시민사회를 비롯한 다양한 이해 관계자를 개발의 주체로 인정하였다. 따라서 시민사회는 정부 이외에도 기업, 의회 및 지방정부 와의 비판적인 협력관계를 증진시킬 필요가 있다. 
가) 기업 감시와 비판적 협력

부산총회의 가장 큰 '수혜자' 가 기업이라는 말이 나돌 정도로 부산결과 문서는 기업의 역할에 대해 민관협력(Public Private Partnership)의 의미가 불분명함에도 불구하고 이제 PPP는 국 제개발협력분야 일상어가 되어가고 있다. 민관협력에서 private는 기업과 시민사회를 포함하 는 개념으로 정부-시민사회-기업이 참여하는 일종의 '삼각협력' 형태를 의미하기도 한다.

개발원조에서 기업의 역할을 기업의 사회적책임(Corporate Social Responsibility) 또는 사 회공헌의 관점에서도 접근할 수도 있다. 시민사회는 민관협력에 한 주체로 참여하면서 동시에 기업이 $\mathrm{OECD}$ 의 다국적 가이드라인, 유엔 인권이사회의 기업과 인권에 관한 가이드라인과 프 레임워크, 글로벌컴백의 10 가지 원칙, ISO 26000 등 기업 활동에 관한 국제적 규범에 따라 이 루어질 수 있도록 감시하고 견인하는 역할을 수행해야 한다.

나) 국회와의 협력

부산총회는 의회와 지방정부가 주민을 정부와 연결시키고 개도국의 개발의제에 대한 폭넓은 민주적 주인의식을 보장하는데 중요한 역할을 한다고 강조하면서 개발사업에 대한 감시 역할을 강조하였다. ${ }^{31)}$ 현재 국회에는 MDGs 포럼과 ODA포럼이 구성되어 있지만 관심과 전문성 부족 으로 인하여 활동이 매우 미비하다. 새로 구성되는 19 대 국회는 국제개발협력 관련 소위를 구성 하여 본격적인 정책감시를 할 필요가 있다.

다) 지방정부와의 협력

부산총회는 지방정부와 의회가 주민을 정부와 연결시키고 개도국의 개발의제에 대한 폭넓은 민주적 주인의식을 보장하는데 중요한 역할을 한다고 명시하면서 지방정부는 단순한 현장에서 서비스 제공하는 수준을 넘어 지역차원에서 주민의 참여와 책무성을 제고하는 역할을 수행해야 한다고 강조하였다. ${ }^{32)}$

31) 제21항 Parliaments and local governments play critical roles in linking citizens with government, and in ensuring broad-based and democratic ownership of countries' development agendas. To facilitate their contribution, we will:

a) Accelerate and deepen the implementation of existing commitments to strengthen the role of parliaments in the oversight of development processes, including by supporting capacity development ?? backed by adequate resources and clear action plans.

32) 제21항 b) Further support local governments to enable them to assume more fully their roles above and beyond service delivery, enhancing participation and accountability at the sub-national levels. 
서울시를 비롯하여 대부분의 지방자치단체는 자체적으로 국제개발협력 예산을 책정해서 사업 을 시행하거나 KOICA와 협력사업을 수행하고 있다. 최근 ODA 액수가 증액하면서 다양한 중 앙 부처 뿐만 아니라 지방자치단체도 국제개발협력에 관심을 가지고 다양한 사업을 추진하고 있다. 국제개발협력의 확산이라는 측면에서는 긍정적 현상이지만 원조효과성의 가장 큰 걸림돌 인 원조파편화 또는 분절화(fragmentation)의 문제가 더욱 심화될 수 있다는 우려 또한 증대 하고 있다. 지자체의 예산 따내기 위한 무분별한 사업 추진은 현장의 요구와 현지 주민의 참여와 관련없는 일방적 사업 추진, 중복, 불필요한 경쟁 등 심각한 부작용을 초래할 수 있다.

현재 경상북도가 의욕적으로 추진하고 있는 새마을운동 해외보급 사업은 지방자치단체의 대 표적인 사업으로 알려져 있다. 그리고 부산총회 때 부산시는 부산 이니셔티브 명칭으로 수산물 가공 기술을 전수하여 태평양 연안 국가의 영양실조 문제를 해결하는 사업을 제시하였다. 이밖 에 지난 10 년간 광주 5.18 재단이 추진해온 광주인권상, 해외단체 지원, 청년인턴 해외파견 등 은 아시아에서의 민주화 분야 개발협력의 좋은 사례가 될 수 있다. 더 나아가 광주광역시가 의 욕적으로 추진하고 있는 세계인권도시포럼(WHRCF) 또한 경제발전에 치우친 한국의 개발경험 공유사업을 보완하고 민주적 개발 또는 민주적 가버넌스의 경험을 공유하는 좋은 사례이기도 하다. ${ }^{33)}$

많은 도시가 해외의 도시와 자매결연을 맺고 있다. 그러나 대부분이 유럽과 북미 중심으로 이 루어지고 있는데 유사한 성격을 지닌 개도국의 도시와 삼각으로 자매결연을 맺고 이를 통해 개 도국 도시와 지방자치단체가 겪는 문제를 해결하는데 실질적인 도움을 주는 방안을 고려해 볼 수도 있다. 이렇듯 지방정부는 중앙정부와 달리 주민의 삶과 보다 밀접한 문제를 직접 다루기 때문에 사업의 효과성을 보다 잘 담보할 수 있는 위치에 있다. 한국의 시민사회 특히 지방의 시 민사회단체 또한 지방자치단체와의 협력 하에 국제개발사업에 참여를 새로운 주민운동의 의제 로 보다 진지하게 고려할 필요가 있다.

\section{4) 정부 관련 과제}

2010년 11월 G20 정상회의에 이어 2011년 11월 부산 세계개발원조총회를 '성공적' 으로 개최 하면서 국제개발분야에서 한국의 위상이 매우 높아졌다. 올해 6 월 리우에서 열리는 '리우+ 20 '

33) 세계인권도시포럼 관련해서는 http://www.humanrightscity.net/ 참조 
에서 공동의장국 역할을 맡게 되면서 국제개발 담론과 정책에서 한국정부의 역할에 대한 관심 과 기대가 계속해서 높아지고 있다. 그러나 이에 비례해서 국제 시민사회 내에서 비판적 목소리 또한 점증하고 있다. 특히 반기문 총장이 성공적으로 두번째 임기를 시작했지만 첫번째 임기 중 식량난과 에너지난, 기후변화 그리고 2008년 발생한 미국발 세계경제위기와 약화되는 국제개 발협력 의제 등에 대해 제때에 제대로 대처하지 못했다는 비판과 맞물리면서 높아지고 있다.

한국정부는 부산총회 주최국가이자 국제개발의 중요 행위자로서 부산파트너십의 국내적 및 국제적 이행에 특별한 책임을 지니고 있다. 이에 따라 한국의 시민사회도 한국정부의 역할을 국 내와 국제에서 모두 감시하고 비판적으로 협력하는 과제를 안고 있다.

가) 이스탄불 원칙 실현을 위한 우호적인 정책 환경(Enabling Environment) 조성

한국정부는 시민사회 관련하여 무엇보다도 국내에서 시민사회가 스스로 만든 이스탄불 원칙 을 잘 실행할 수 있도록 필요한 정책과 제도적 환경을 조성하는데 우선적인 노력을 기울여야 한 다. 이스탄불 원칙을 가장 먼저 공개적으로 지지하여 부산총회 문서에 이스탄불 원칙이 반영되 는데 결정적 기여를 한 한국정부는 이행에도 모범을 보여 정책일관성을 보여줄 필요가 있다. 특 히 시민사회의 개발효과성 실현을 가능케 하는 정책과 제도적 환경(enabling environment) 조성에 각별한 노력을 기울여야 한다. 이와 관련하여 한국정부는 Open Forum이 제시한 공여 국과 수원국 정부가 지켜야 할 원칙을 고려하여 구체적인 정책과 제도 개선 노력을 해야 한 다. ${ }^{34)}$ 이러한 원칙들은 단순히 시민사회에 대한 재정지원 확대나 사업 영역 확대 수준을 넘어 서 시민사회를 명실상부한 개발협력의 파트너로 인정하고 협력할 것을 정부에게 요구하고 있 다. 따라서 이러한 과제는 한국정부 독자적으로는 수행이 불가능하고 수원국의 정부와 시민사 회와의 협력이 매우 필요하다. 이 과정에서 한국 시민사회의 효과적 개입이 요구된다.

34) Open Forum은 2010년 이스탄불 총회에서 시민사회 개발효과성 제고와 관련하여 이를 가능하게 하는 정책 및 제도적 환경(enabling environment) 관련하여 개도국(수원국)과 선진국(공여국) 정부가 지켜야할 최소한의 기준 을 제시하였다. 수원국 정부 관련 5 개의 기준은 첫째 독립성과 자체규제이며, 둘째는 CSO에 대한 승인이다. 셋 째는 실제로 작동되는 법적체계이고, 넷째는 파트너십과 기술적 지원이다. 마지막 다섯째는 투명성, 개방성 그리 고 책임성이다. 공여국 관련 6 가지 기준은 첫째 $\mathrm{CSO}$ 의 독립성과 자율성 그리고 $\mathrm{CSO}$ 역할의 다양성에 대한 인 정과 지지, 청렴성과 윤리적 실행이다. 둘째 기준은 개발행위자로서의 CSO를 지지하는 지속적이고, 투명하며 일 관성 있는 정책, 공여자의 전략에 대한 정보공유, 개도국과 신흥국가에서의 개발효과성의 주요 추동자로서의 $\mathrm{CSO}$ 에 대한 인식, 지역의 지식과 문화적으로 관련된 역량의 장려, 양성평등과 여성권리 촉진, 공여자 자문그룹 의 구성에 참여이다. 셋째 기준은 파트너십을 존중하는 것으로 $\mathrm{CSO}$ 의 목표와 미션을 존중하는 파트너십 형성과 $\mathrm{CSO}$ 가 수립한 프로그램에 대한 존중 및 직간접적 재정지원이다. 넷째는 CSO개발효과성을 위한 재정지원 조건, $\mathrm{CSO}$ 신용기금을 위한 다자간지원 및 재정지원협약에 대한 정부의 적절한 책임성이며, 다섯째 기준은 투명성과 모범적 가버넌스(good governance)이다. 정보에 대한 현지 CSO의 접근도 중요하다. 마지막 여섯째 기준은 $\mathrm{CSO}$ 의 정책대화 참여 촉진과 공적 정책개입 활동에 대한 지지이다. 
나) 원조 분절화 극복과 정책일관성

원조 분절화는 원조효과성의 가장 구조적인 걸림돌로 반복해서 지적되어 왔지만 제대로 개선 되지 않는 대표적 문제로 알려져 있다. 최근 국무총리실의 국제개발협력 자문위원회 논란에서 드러났듯이 최근 한국정부의 국제개발협력 정책은 부산파트너십의 정신과 달리, 개발협력사업 의 확산과 정부부처간 참여 확대라는 명분하에 원조분절화를 더 심화하는 방향으로 정책이 만 들어지고 있다는 시민사회의 비판이 있었다. 수많은 국민 세금으로 운영되는 ODA가 부처간의 예산 확보 경쟁의 대상으로 전락하는 것을 방지하기 위해서라도 국제개발협력의 정책일관성 (Policy Coherence for Development)은 우선적 정책과제이다. 이 과제가 해결되지 않고서는 $\mathrm{ODA}$ 의 양적 증대가 질적 저하를 가져와 의도와 달리 $\mathrm{ODA}$ 증액이 오히려 부작용만 더 일으키 는데 기여한다는 우려가 높아지고 있다.

이와 관련하여 올해 6월 시행되는 OECD 개발원조위원회(DAC) 동료평가(Peer Review)가 주목을 받고 있다. 2009년 11월 OECD DAC 가입에 따라 한국정부는 올해 동료평가를 받을 예 정이다. 한국정부의 국제개발협력 정책을 국제기준에 비추어 종합적으로 살펴볼 수 있는 좋은 기회를 적극적으로 활용하기 위해 이미 여러 시민사회단체가 대안적 보고서를 준비하기 시작하 는 등 올해의 중요한 과제로 부상하였다.

다) 독립적인 개발원조청 설립

마지막으로 올해 12 월 대통령 선거 공약으로 독립적인 개발원조부처를 설립하는 안은 시민사 회안에서 높은 관심과 지지를 받고 있다. 한때 다소 이르다는 주장이 있었지만 최근 카메룬 $\mathrm{CNK}$ 사건을 계기로 이러한 문제를 구조적으로 예방하는 제도적 방안으로 독립적이고 통합적으 로 국제개발협력 업무를 전담하는 개발원조부처가 필요하다는 공감대가 형성되고 있다. CNK 사건에서 드러났듯이 자원외교 명분의 '국익' 중심 외교수단으로 활용되는 원조자금은 다양한 이해관계자의 '사익' 추구의 도구로 변질되곤 한다. 국민의 세금인 원조 자금이 가난한 국가의 주민의 복지와 인권증진에 기여하기 위해서는 국익이 아니라 보편적 가치와 공익을 우선적으로 고려할 수 있도록 원조기관의 독립성과 자율성을 강화해야 한다. 현재 이미지 제고 위주의 '국 위' 선양과 부처간의 '밥그릇 키우기' 대상이 된 원조자금 증액과 원조자금 집행 권한을 둘러싼 문제를 제도적으로 해결하는 방안으로 독립적인 개발원조부처 설립 문제에 대해 시민사회는 총 선을 계기로 보다 적극적으로 고민하고 캠페인을 조직할 필요가 있다. 


\section{참고문헌}

\section{1. 국내문헌}

국제개발협력시민사회포럼(KoFID), "부산 세계개발원조총회(HLF-4)에 대한 입장과 정책제언 (포지션 페이퍼)", 2011년 8월

김혜경, 2009, "국제시민사회의 이슈와 한국시민사회의 대응과제" 제 5 회 ODA Watch 지구촌포럼 자료

손혁상 외, 2011, 「개발효과성 제고를 위한 정부-시민사회 협력방안 연구」. KOICA 연구보고서. 한국국제협력단 (출판 예정)

손혁상, "부산개발원조총회(HLF-4)와 세계시민사회의 대응전략: BetterAid와 Open Forum을 중심으로”, 국제개발협력 (2011, No 3), 한국국제협력단

이성훈, “국제개발협력과 인권 : 부산 제4차 $\mathrm{OECD}$ 원조효과 고위급회의 (세계개발원조총회)와 한국의 역할” 국제개발협력 (2011, No 1), 한국국제협력단

이성훈, “민주주의와 국제개발협력·한국의 민주화 경험과 ODA", 국제개발협력 (2011, No 3), 한국국제협력단

이성훈, “시민사회가 바라보는 부산총회의 성과와 향후 과제” 국제개발협력 (2011, No 4), 한국국제협력단

이태주, "부산 HLF-4 이후 한국의 과제: 시민사회의 관점", 부산. HLF-4이후의 세계원조체 계와 한국의 과제, 2011 국제개발협력학회 정기학술회의

한재광, 2010, “지구촌 빈곤감축을 위한 시민사회의 노력” 「국제개발협력」2010년 제4호, 한국국제개발협력단 